\title{
Educational Leadership in the Solomon Islands: Training Principals for Quality Schooling
}

\author{
John Iromea \\ University of Sydney
}

The importance of educational leadership training for school principals in the Solomon Islands is identified. Training and development of secondary school principals is an increasingly important part of a principal's professional repertoire as the many and complex roles of this position change. This study investigates the training needs of principals in the Solomon Islands. It adopts a quantitative case study approach using a survey questionnaire. Results gathered from 19 school principals are presented in tables and discussed. Priority areas for improving principal leadership are identified-the need for gender-balance in leadership appointment, and training for aspiring school leaders.

Keywords: education, leadership, training, school principals, Solomon Islands, South Pacific

\section{INTRODUCTION}

The demand for quality education has become increasingly important worldwide. Integral to achieving quality education is ensuring sustainable policies and practices amongst school principals. Over the last 3 decades, there has been considerable emphasis on achieving Sustainable Development Goals (SDGs) in terms of equitable access, improving quality, and effective leadership (UNESCO, 2002). More recently, improving educational policies and practices have become main foci of nations worldwide, as governments realize that access to quality education and effective management of educational resources leads to quality outcomes. According to the National Education Action Plan for 2013-2015 (MEHRD, 2013) and the Education Strategic Plans 2016-2030 (MEHRD, 2016), there are three fundamental strategic goals to improve the standard of education in the Solomon Islands. These are: 1) achieve equitable access to education for all people in the Solomon Islands; 2) improve quality of education in the Solomon Islands; and 3) manage and monitor resources efficiently and cost-effectively (MEHRD, 2016, p.12).

Significant challenges exist to achieving these strategic education goals in the Solomon Islands, particularly their alignment and implementation within broader UNESCO SDGs. Implementation and assessment processes have not been fully utilized due to slow progress and limited support. Moreover, lack of data and research available to educational leaders hamper informed implementation of improved and more effective ways of leading and managing the secondary school education system in small island nations (Baldacchino \& Faruggia, 2002). It is unknown if school leaders are aware or fully conscious of their leadership and management practices and responsibilities, and even if so, the limited support from the national government is one factor that often hinders leadership initiative. A substantial body of research explores the leadership practices in many 'western' contexts, yet scant research has examined 
aspects of educational leadership in non-western contexts, including in so-called small states, and how teachers experience the leadership practices of principals in their schools.

\section{CONCEPTUAL FRAMEWORK}

This paper draws from recent findings that educational leadership training brings about quality teaching and learning (Hallinger \& Heck, 2006; Sebastian, Huang, \& Allensworth, 2017). Hence, effective school leaders tend to influence school success in terms of developing clear school goals (Malpo, 2011), improving school culture (Hargreaves, 2006), and promoting a healthy learning environment (MacNeil, Prater, \& Busch, 2009). This paper further highlights that effective school leaders are good at utilizing educational leadership policies and practices to improve access, quality teaching, and learning within the education system in the Solomon Islands. Sanga (2002) demonstrated that systematic rethinking about development changes and community involvement in those changes is important, because the problems of educational achievement and academic success demand resources beyond the scope of schools and most families. Hence, educational leadership training for school leaders is of significance in the Solomon Islands for the next 10 years, to 2030 (MEHRD, 2016). While the Solomon Islands maintains a national bureaucratic education system, such as salaries, policy, and decision-making mechanisms, successive governments aim to devolve some responsibilities to Local Education Authorities (EA's) and communities. The government considers EA's must assist in management, administration, delivery, and maintenance of education services at provincial and regional levels (Solomon Islands Government, 2017; Rodie, 2014). Such decentralization approaches move at a plodding pace, not only due to lack of resources but also due to the lack of appropriate training to prepare school leaders to carry out those responsibilities within school settings

Roles of school principals are many. They perform critical functions such as head teacher, chief accountant, chief administrator, and expert public relations officer (Maha, 2003), who further asserted that "the complexities of the roles and functions dictate that those who assume the principalship must be well trained and prepared to perform these duties effectively and efficiently" (p.30). However, leadership training and development of school leaders in the Solomon Islands is becoming increasingly complex nationwide, because of the topography of this island nation (Sanga et al., 2020). Worst still, for years principals have had limited training and preparation in areas of educational administration (Pounder \& Merril, 2001). This lack of training and development continues to affect the administrative roles of principals in schools. Unless adequate and relevant training are provided for a principalship position, principals will continue to find the roles of effective and efficient management of schools a challenge (Hallinger \& Heck, 2010).

\section{RESEARCH CONTEXT AND METHODS}

Over the last decade in Honiara, the capital city of the Solomon Islands, there has been rapid growth in the number of Secondary Schools. In the early 1990s, in Honiara alone, many Community High Schools were added onto existing schools in response to community support and pressure. Based on Millennium Development Goals (MDG) and Education for All (EFA) goals to provide all children, youth, and adults around the world access to education (UNESCO, 2002; Townsend \& Cheng, 2000), the National Education Board and Cabinet (National Government) established a National Strategic Framework for the 15-year period (2016-2030), focusing on three fundamental pillars for sustainable development. Strategic goals included: 1) to achieve equitable access to education for all people in the Solomon Islands, 2) to improve the quality of education in the Solomon Islands, and 3), to manage and monitor resources efficiently and cost-effectively (MEHRD, 2016, p.12). The Solomon Islands government emphasized that access, equality, and quality education for all Solomon Islanders, regardless of gender, background, or ability, was fundamental.

Because of community pressure and high demand from Ministry of Education and Education Authorities, the role of the principal has become an essential position in education. A big part of that job 
is to implement the National Strategic Goals of 'Access,' 'Quality,' and 'Management' in the school. Hence, the principal must be concerned with the integration of these three pillars with that of the whole school development plan, of which the teachers, students, and parents are not least significant. Another significant challenge for the Solomon Islands education system, the alignment and implementation of these strategic goals with the broader UNESCO Millennium Development Goal, remains unsolved (MEHRD, 2016). While it is true that many government policies have strategized under MEHRD's action plan for 2016-2030, the implementation and assessment processes have not been fully utilized. Unresolved issues relating to inadequate research on the professional development of school leaders with relevant leadership approaches require immediate attention if the Solomon Islands government is to achieve long-term sustainable results. Unfortunately, it is unknown if school leaders are aware or fully conscious of their leadership and management practices and responsibilities, and even if so, whether these are adequately applied to improve the teaching and learning programs to fulfill government educational expectations.

This paper reports on findings from a case study of one important group of actors-principals - and their training towards increased quality with effective leadership, drawing on the responses to questions of 19 secondary school principals in Honiara.

\section{DATA, FINDINGS, AND DISCUSSION}

Education leadership is conceptualized in ways unique to the Pacific Islands, and more specifically, the Solomon Islands. Ways in which education actors can re-imagine and strengthen leadership practices to improve education policy development and implementation in the Solomon Islands are identified. These findings are grounded in a local context, taking into account the cultural, historical, geographical, and economic conditions that may enable future success in improving principals' leadership position, experiences, qualifications, and training.

\section{Principal Position}

Within the Honiara education system, principals are primarily male, have served less than 5 years, with 3 or less of those years spent as principals in two or three schools. After spending an average of 2-3 years in a school, they transferred to another school or secured a job elsewhere. Many principals were SICHE graduates with a diploma in secondary teaching. Before and after assuming the principalship, they completed some short-term in-service training courses, many of which focused on management more so than leadership functions. Of 19 respondents, $16(84.2 \%)$ were male, and $3(15.8 \%)$ were female.

Secondary school principalship in the Honiara education system is becoming localized and dominated by males. While in developed countries, like the United States of America, the number of female principals is increasing (Buckner, 2009), in developing countries, females are often underrepresented at this level of administrative responsibility. While this study did not address the reasons for such a gender imbalance, Beltran (2000a) and Maha (2003) stressed that principalship roles are many and complex, and this complexity may have contributed to this imbalance. Many principals in Honiara secondary schools served for a very short time. As Maneipuri (in USPIE, 2002) alluded to, they are inexperienced because of a lack of appropriate training.

Men and women should be equal partners in the leadership and management process (Maha, 1999), with Beltran (2000a) stating both could provide effective leadership and management in the school system. If the Honiara education system wants to develop partnerships, it would be prudent to invest in preparing women for management and leadership roles. Women are being increasingly educated and have dominated teaching positions.

\section{Principal Experiences}

Most Honiara secondary school principals are inexperienced, having served 1-2 years in this role (58\% had served less than 5 years in the principalship position (Table 1), and $84 \% 3$ years or less (Table 2)). 
TABLE 1

PRINCIPALSHIP EXPERIENCE (YEARS)

\begin{tabular}{|c|c|c|}
\hline Years & No. & Percentage (n= 19) \\
\hline$<5$ & 11 & 57.9 \\
\hline $6-10$ & 7 & 36.8 \\
\hline $11-15$ & 1 & 5.3 \\
\hline $16-20$ & 0 & 0.0 \\
\hline $21-25$ & 0 & 0.0 \\
\hline$>25$ & 0 & 0.0 \\
\hline Total & $\mathbf{1 9}$ & $\mathbf{1 0 0 . 0}$ \\
\hline
\end{tabular}

TABLE 2

NUMBER OF YEARS AS PRINCIPAL

\begin{tabular}{|c|c|c|}
\hline Number of Year(s) & No. & Percentage $(\mathbf{n}=\mathbf{1 9})$ \\
\hline 1 & 7 & 36.8 \\
\hline 2 & 3 & 15.8 \\
\hline 3 & 6 & 31.5 \\
\hline 4 & 1 & 5.3 \\
\hline 5 & 1 & 5.3 \\
\hline$>5$ & 1 & 5.3 \\
\hline Total & $\mathbf{1 9}$ & $\mathbf{1 0 0 . 0}$ \\
\hline
\end{tabular}

This study agrees with Jules (2012), that this situation for small island states came about because many principals in secondary schools did not acquire desirable expertise. Two deficiencies experienced by many Pacific Island countries are associated with novice principalship (Teacher Education Division, 1987): 1) many principals had moved straight from the classroom into an administrative position. Since 'good' classroom teachers frequently assume principalship without preparation, they may begin administering with limited experience. 2) potential administrators lack practical facilities. A teacher trainee has opportunities provided to them to practice teaching during their college life, but rarely do educational administrators have access to an administrative situation where they can practice in a way a teacher trainee practices.

Principalship may not be a life-long career, but a springboard for promotion to another position (Maha, 1999). Principals seemingly abandon their job early and move to greener pastures elsewhere, with most principals in PNG replaced or transferred after completion of 2 years (Maha, 2003). Such short-term service hinders long-term school planning, development, and continuity.

\section{Principal Qualifications}

Many Honiara secondary school principals lack adequate qualifications and preparation for principalship. Although they possess a variety of educational and professional skills, most entered teaching service with teaching qualifications; there is no specific preservice qualification for principalship.

The majority $(\sim 95 \%)$ of principals acquired their teaching qualifications at a preservice level, with $\sim 53 \%$ possessing a diploma in secondary school teaching, and $\sim 32 \%$ a degree qualification (Table 3 ). Fewer principals received in-service qualifications before and after assuming the position of principalship (Tables 4,5 ). No principal had a postgraduate qualification. Other principals had degrees in a variety of disciplines unrelated to teaching or education. 
TABLE 3

PRESERVICE QUALIFICATIONS COMPLETED BY PRINCIPALS

\begin{tabular}{|c|c|c|}
\hline Preservice qualifications completed & No. & Percentage $(n=19)$ \\
\hline Form $3+3$ years Diploma from SICHE & 0 & 0.0 \\
\hline Form $5+3$ years Diploma from SICHE & 8 & 42.1 \\
\hline Form $6+3$ years Diploma from SICHE & 1 & 5.3 \\
\hline Form $7+3$ years Diploma from SICHE & 0 & 0.0 \\
\hline Bachelor of Education (BEd) from UOG & 1 & 5.3 \\
\hline Other(s) & 9 & 47.3 \\
\hline Total & 19 & 100.0 \\
\hline
\end{tabular}

TABLE 4

IN-SERVICE QUALIFICATIONS RECEIVED BY PRINCIPALS

\begin{tabular}{|l|c|}
\hline \multicolumn{1}{|c|}{ In-service qualifications received } & Percentage $(\mathbf{n}=\mathbf{1 9})$ \\
\hline College Diploma $(\mathrm{n}=2)$ & 10.5 \\
\hline University Diploma $(\mathrm{n}=2)$ & 10.5 \\
\hline Bachelor of Education Degree $(\mathrm{n}=5)$ & 26.3 \\
\hline Bachelor of Education Degree (Hons) $(\mathrm{n}=0)$ & 0.0 \\
\hline Postgraduate Diploma in Education (PDGE) $(\mathrm{n}=0)$ & 0.0 \\
\hline Master's Degree in Educational Administration $(\mathrm{n}=0)$ & 0.0 \\
\hline Other(s) $(\mathrm{n}=3)$ & 15.8 \\
\hline
\end{tabular}

TABLE 5

IN-SERVICE QUALIFICATIONS RECEIVED BY PRINCIPALS AFTER ASSUMING PRINCIPALSHIP

\begin{tabular}{|l|c|}
\hline \multicolumn{1}{|c|}{ In-service qualifications received } & Percentage $(\mathbf{n}=\mathbf{1 9})$ \\
\hline College Diploma $(\mathrm{n}=1)$ & 5.3 \\
\hline University Diploma $(\mathrm{n}=0)$ & 0.0 \\
\hline Bachelor of Education Degree $(\mathrm{n}=3)$ & 15.8 \\
\hline Bachelor of Education Degree (Hons) $(\mathrm{n}=0)$ & 0.0 \\
\hline Postgraduate Diploma in Education (PDGE) $(\mathrm{n}=0)$ & 0.0 \\
\hline Masters Degree in Educational Administration $(\mathrm{n}=0)$ & 0.0 \\
\hline Other(s) $(\mathrm{n}=1)$ & 5.3 \\
\hline
\end{tabular}

According to MEHRD (2006), principals with diploma qualifications constituted the highest percentage of teachers graduating from SICHE. The minimum entry requirement for these teachers to join teaching service is a diploma in teaching from a teacher institution. Maha, Flaherty, Sinebare, Onagi, and Kaleva (2000) reported the main aim and purpose of offering such preservice qualifications was to prepare potential personnel in any secondary school teaching subject to be able to teach.

In the USA education system, potential personnel must have a principals' license before assuming principalship (Buckner, 2000). In the Philippines, principals need a Master's Degree in Educational Administration to effectively manage and lead a school (Beltran, 2000b). Maha (1999) reported that to have principals with adequate qualifications it was essential that they enter the teaching profession with more degrees than at their preservice level. In doing so, teachers wishing to assume principalship would be more capable of performing their roles with confidence. 
Cole (1999) and Kouali (2017) asserted that for principals to have sufficient knowledge and be highly regarded, they needed a higher and adequate level of training, and advanced university qualifications before assuming principalship.

Many Honiara secondary school principals assumed principalship positions based on diploma qualifications and teaching experiences. This does not always mean that an experienced teacher is a better candidate for a principal position. Having teaching experience is one thing, and having adequate degree qualifications is another. If the Honiara education system is to have qualified personnel as principals, then qualification authorities must upgrade the principals' qualification from diploma to degree level. Accordingly, the Ministry of Education and Human Resource Development (MEHRD) and teacher training institutions must provide opportunities for teachers and principals to acquire a higher degree qualification in education to increase their confidence and competence in job performance.

\section{Principal Training}

In past decades, educational administrators were confronted by many complex tasks and responsibilities (Beltran, 2000a). Principals were unprepared, often not recognizing that rapid and complex administrative changes were occurring. Advanced training of secondary school principals is necessary to enable them to fulfil their administrative responsibilities; current training is inadequate and short term, and does not adequately address the nature and extent of functions needed for a school to run effectively. Many secondary school principals are inadequately trained (Table 6). Although courses seem to attract a large number of principals (Table 7), only half of the total population was involved in each inservice course. For most on-the-job courses, there was more emphasis on management functions and less on professional and curriculum development.

At a preservice level, Sanga, Chu, Hal, and Crowl (2004) commented that educational training is vital to prepare a person to be a teacher. As such, preservice training is usually a long-term program that purposely prepares students to become teachers in the school system (Kiruhia, 2003). In-service training, on the other hand, focuses on both long- and short-term training for experienced teachers to be principals. Thus, on-the-job training programs could improve the skills and knowledge of teachers within the system, to assist them to become competent to perform a role as principal. According to the Australian Academy of Science (2011), the quality of school performance is dependent on effective school leaders, which in turn is dependent on the quality of training at teaching institutions.

Although many Honiara City principals participated in short-term in-service courses before and after being promoted into principalship, training was not regular. Sanga, Chu, Hal, \& Crowl (2004) reported inservice training to not always be available (p.103). Consequently, untrained principals find the work of school principals increasingly difficult and time-consuming.

Although principals worked collegially with staff as a professional team, and made sacrifices by spending time with students and staff, they lacked adequate formal training from any recognized institution. Principals had little training before assuming principalship, receiving role-specific training only after assuming the position (Maha, 1999). This approach to preparation for principalship has existed for decades, and it is now a concern. Historically, training had been informal, with deputy principals merely observing and imitating colleagues (principals). 


\section{TABLE 6}

\section{DISTRIBUTION (\%) OF IN-SERVICE TRAINING COURSES COMPLETED PRIOR TO}

PRINCIPALS ASSUMING PRINCIPALSHIP

\begin{tabular}{|l|c|}
\hline \multicolumn{1}{|c|}{ In-service courses completed } & Percentage $(\mathbf{n}=\mathbf{1 9})$ \\
\hline Bachelor of Education (In-service) $(\mathrm{n}=5)$ & 26.3 \\
\hline Bachelor of Arts (In-service) $(\mathrm{n}=0)$ & 0.0 \\
\hline Educational Administration $(\mathrm{n}=2)$ & 10.5 \\
\hline Principals' Course on General School Administration $(\mathrm{n}=7)$ & 36.8 \\
\hline Principals' Course on Financial Management $(\mathrm{n}=7)$ & 36.8 \\
\hline Principals' Course on Professional Development $(\mathrm{n}=5)$ & 26.3 \\
\hline Principals' Course on Curriculum Implementation $(\mathrm{n}=5)$ & 263 \\
\hline Other(s) $(\mathrm{n}=7)$ & 36.8 \\
\hline
\end{tabular}

TABLE 7

DISTRIBUTION (\%) OF IN-SERVICE COURSES COMPLETED BY PRINCIPALS AFTER ASSUMING PRINCIPALSHIP

\begin{tabular}{|l|c|}
\hline \multicolumn{1}{|c|}{ In-service courses completed } & Percentage $(\mathbf{n}=\mathbf{1 9})$ \\
\hline Bachelor of Education (In-service) $(\mathrm{n}=3)$ & 15.8 \\
\hline Bachelor of Arts (In-service) $(\mathrm{n}=0)$ & 0.0 \\
\hline Educational Administration $(\mathrm{n}=0)$ & 0.0 \\
\hline Principals Course on General School Administration $(\mathrm{n}=5)$ & 26.3 \\
\hline Principals' Course on Financial Management $(\mathrm{n}=11)$ & 57.9 \\
\hline Principals' Course on Professional Development $(\mathrm{n}=7)$ & 36.8 \\
\hline Principals' Course on Curriculum Implementation $(\mathrm{n}=7)$ & 36.8 \\
\hline Other(s) $(\mathrm{n}=4)$ & 21.1 \\
\hline
\end{tabular}

Solomon Islands teachers and principals need continued training to improve their skills prior to assuming the role as principal, and afterwards to remain abreast of ever-evolving responsibilities. For effective accomplishment of a principal's tasks and responsibilities, prolonged and more comprehensive training at a university level, and on-going short-term in-service training within the school system, should be considered by education authorities. A principal's tasks and responsibilities can only be meaningfully executed with adequate and relevant training.

\section{IMPLICATIONS AND CONCLUSIONS}

I demonstrate principalship in the Honiara education system to be highly localized. Most principals are male, and occupy their position with limited experience. Novice principals tend to serve 3 or less years in schools before leaving a position, only for it to be filled by another inexperienced principal, in a cycle that must be broken. Such short-term service hinders long-term or strategic school planning, development, and continuity. Principals are also inadequately trained and qualified to handle the position of principalship.

The qualifications of principals determine their confidence and ability to perform administrative duties (Maha, 1999). Quality educational leadership training produces quality teaching and learning (Hallinger \& Heck, 2006; Sebastian et al., 2017), with effective school leaders tending to promote healthy learning environments (MacNeil et al., 2009).

For principals to perform and accomplish their given tasks, they require skills and knowledge obtained through relevant training, which should be prolonged, complemented with on-going short-term in-service programs for those who assume principalship. More competent principals improve the school 
environment, making it a better place for teaching and learning to take place. One never sees a good school with a poor principal or a poor school with a good principal (Beltran, 2000b).

\section{RECOMMENDATIONS}

1. The Ministry of Education and Human Resource Development (MEHRD) and education authorities should equally consider females for appointment to school principals.

2. Continued short-term on-the-job training of principals is urged. Courses should focus on administration, financial management, ethical development, instructional leadership, and curriculum implementation. Training could be conducted regularly for 1 or 2 weeks during term and semester breaks.

3. Further research is necessary. As findings of this case study may be unique to urban schools in Honiara City, study at greater spatial and temporal scales would prove valuable, both within the Solomon Islands, and throughout the Pacific.

\section{ACKNOWLEDGEMENTS}

I thank Dr Steve O'Shea, DrO-Editing.com, for his assistance with the editing an earlier draft of this manuscript. And I acknowledge Solomon Islands Government sponsorship for funding assistance.

\section{REFERENCES}

Australian Academy of Science. (2011). Leading for change: A stimulus for professional discussion. Canberra: Australian Academic of Science.

Baldacchino, G., \& Faruggia, C. (Eds.). (2002). Educational planning and management in small states: Concepts and experiences. Commonwealth Secretariat.

Beltran, P.A.C. (2000a, September). The roles of the school administrator. The Modern Teacher, 49(4), 128-153. Manila: Member Pap Publishers Association of the Philippines, Inc.

Beltran, P.A.C. (2000b, January). Management and leadership in school. The Modern Teacher, 48(8), 180-185. Manila: Member Pap Publishers Association of the Philippines, Inc.

Buckner, K.B. (2009). School principal-The role of elementary and secondary school principals, principal duties and responsibilities, principal qualifications. Retrieved November 20, 2009, from http://education.stateuniversity.com/pages/2333/Principal-School.html

Campbell, R.F., Corbally, J.E., \& Nystrand, R.O. (1983). Introduction to educational administration (6th ed.). Boston, MA: Allyn \& Bacon.

Cole, M. (1999). Professional issues for teachers and student teachers. London: David Fulton.

Griffith, J. (1999). School leadership and school climate relation: Identification of school configurations associated with changes in principals. Retrieved November 25, 2009, from http://eaq.sagepub.com/cgi/content/abstract/35/2/267

Hallinger, P., \& Heck, R.H. (2006). Exploring the principal's contribution to school effectiveness: 19801995. An International Journal of Research, Policy and Practice, 9(2), 157-191.

Hallinger, P., \& Heck, R.H. (2010). Collaborative leadership and school improvement: Understanding the impact on school capacity and student learning. School Leadership and Management, 30(2), 95110.

Hallinger, P., \& Heck, R.H. (2010). Leadership for learning: Does collaborative leadership make a difference in school improvement? Educational Management Administration \& Leadership, 38, 654. Sage. DOI: $10.1177 / 1741143210379060$

Hargreaves, D.H. (2006). School culture, school effectiveness, and school improvement. An International Journal of Research, Policy and Practice, 6(1), 23-46.

Jules, T.D. (2012). Re-reading the anamorphosis of educational fragility, vulnerability, strength in small states. Current Issues in Comparative Education, 15(1), 5-13. 
Kiruhia, J.B. (2003). The Practicum as experienced in the student-teacher role. In AC. Maha \& T.A. Flaherty (Eds.). Education for 21st Century in Papua New Guinea and the South Pacific (p.109). Goroka: UOG.

Kouali, G. (2017). The instructional practice of school principals and its effect on teachers' job satisfaction. The International Journal of Educational Management, 31(7), 958-972. Retrieved from http://ezproxy.library.usyd.edu.au/login?url=https://search.proquest.com/docview/1933866000?ac countid $=14757$

MacNeil, A.J., Prater, D.L., \& Busch, S. (2009). The effects of school culture and climate on student achievement. Journal International Journal of Leadership in Education, 12(1), 73-84.

Maha, A. (1993). Promotion to the principalship: A comparison of Papua New Guinea and western experience. Offprint from the International Journal of Educational Development, 13(2), 171-182. Great Britain: Pergamon Press.

Maha, A.C., Flaherty, C., Sinabare, M., Ongai, G., \& Kaleva, W. (2000). Educational reform and demand for teachers. Training needs analysis for secondary school teachers in Papua New Guinea. Research Report prepared for the Papua New Guinea Department of Education. Goroka: University of Goroka.

Maha, A.C. (2003). Towards developing a sustainable training program for the principalship: Principals' perception of the usefulness of the training courses completed for the principalship. In A.C. Maha \& T.A. Flaherty (Eds.), Education for 21st Century in Papua New Guinea and the South Pacific (pp. 30-44). Goroka: University of Goroka.

Malpo, K.D.K. (2011). Strategic management and leadership for school managers in the southwest Pacific. Port Moresby: University of Papua New Guinea.

Maneipuri, J. (2002). Solomon Islands education: Issues and challenges. In USPIE (Ed). The Tree of Opportunity: Re-thinking Pacific Education. Suva: The University of South Pacific.

Ministry of Education and Human Resource Development. (2006). MEHRD Annual Report, 2006. Honiara, Solomon Islands: MEHRD.

Ministry of Education and Human Resource Development. (2013). Solomon Islands national education action plan 2013-2015. Honiara, Solomon Islands: MEHRD.

Ministry of Education and Human Resource Development. (2016). Solomon Islands government education strategic framework 2016-2030. Honiara, Solomon Islands: MEHRD.

National Department of Education. (2001). State of education in Papua New Guinea. Port Moresby: NDOE.

Pounder, M., \& Merril, J. (2001). Job desirability of the high school principalship: A job choice theory perspective. In F. Geijsel (Ed.), Educational Administration Quarterly, 37(1), 83-85.

Rodie, F. (2014). Summative assessment practices of Solomon Islands year nine science teachers. (Unpublished PhD Thesis) The University of Waikato, Hamilton, New Zealand.

Sanga, K. (2002). Re-thinking educational reform in Solomon Islands. In University of the South Pacific Institute of Education, The Tree of Opportunity: Re-thinking Pacific Education (p.195). Suva: University of South Pacific.

Sanga, K., Chu, C., Hall, C., \& Crowell, L. (2004). Rethinking aid relationships. Suva: Pacific Education Institute for Research and Development.

Sanga, K., Maebuta, J., Johansson-Fua, S., \& Reynolds, M. (2020). Re-thinking contextualisation in Solomon Islands school leadership professional learning and development. Pacific Dynamics: Journal of Interdisciplinary Research, 4(1), 17-29.

Sebastian, J., Huang, H., \& Allensworth, E. (2017). Examining integrated leadership systems in high schools: Connecting principal and teacher leadership to organizational processes and student outcomes. An International Journal of Research, Policy and Practice, 28(3), 463-488.

Solomon Islands Government. (2017). Solomon Islands governance program design document July 2017-June 2021. Honiara, Solomon Islands: SIG.

102 Journal of Leadership, Accountability and Ethics Vol. 17(4) 2020 
Teacher Education Division. (1987). Social Mosaic: Becoming a teacher in Papua New Guinea. Port Moresby: Teacher Education Division.

Townsend, T., \& Cheng, Y.C. (Eds.) (2000). Educational change and development in the Asia-Pacific Region: Challenges for the future. The Netherlands: Swets \& Zeitlinger B.V. Lisse.

United Nations Educational, Scientific, and Cultural Organisation. (2002). Educational for all: Is the world on track? EFA Global Monitoring Report, 2002. Paris: UNESCO. 